\title{
Krzysztof Mosionek
}

Okręgowa Izba Radców Prawnych, Kielce

mosionek.law@gmail.com

ORCID: https://orcid.org/0000-0003-3269-7167

\section{Postępowanie restrukturyzacyjne wobec deweloperów}

http://dx.doi.org/10.12775/SIT.2020.013

\section{Wprowadzenie}

Odrębne postępowanie naprawcze dedykowane deweloperom, uregulowane w art. 349-361 Ustawy z dnia 15 maja 2015 r. - Prawo restrukturyzacyjne ${ }^{1}$, stanowi odpowiedź na potrzebę szczególnej ochrony praw nabywców mieszkań, będących stronami umów deweloperskich. Wyrazem tejże ochrony jest modyfikacja celów postępowań prowadzonych wobec deweloperów, w stosunku do postępowań prowadzonych na zasadach ogólnych. Celem „klasycznego” postępowania restrukturyzacyjnego jest uniknięcie ogłoszenia upadłości dłużnika przez umożliwienie mu restrukturyzacji w drodze zawarcia układu $z$ wierzycielami, a w przypadku postępowania sanacyjnego - również przez przeprowadzenie działań sanacyjnych, przy zabezpieczeniu słusznych praw wierzycieli (art. 3 p.r.). Natomiast postępowanie w stosunku do deweloperów prowadzone jest w celu doprowadzenia do zaspokojenia nabywców w drodze przeniesienia na nich własności lokali, o ile racjonalne względy na to pozwolą (art. 352 p.r.). Niewątpliwie przyjęcie powyższej regulacji stawia

${ }^{1}$ Ustawa z 15 maja 2015 r. - Prawo restrukturyzacyjne (Dz.U. poz. 978), dalej: p.r. 
wierzycieli - nabywców, w pozycji uprzywilejowanej w stosunku do dłużnika - dewelopera. W doktrynie nie ma jednak jednolitego stanowiska, czy art. 352 p.r. należy interpretować jako przełamanie zasady prymatu interesu ogółu wierzycieli. Dariusz Chrapoński, w przeciwieństwie do większości komentatorów ${ }^{2}$, nie zgadza się z tezą o uprzywilejowanym statusie wierzycieli-nabywców w stosunku do pozostałych wierzycieli dewelopera. Interpretuje on natomiast brzmienie art. 352 p.r. jako wytyczną dla kolejności sposobu restrukturyzacji, która w pierwszej kolejności powinna zmierzać do przeniesienia własności nieruchomości na nabywców, ale jeśli nie znajduje to ekonomicznego uzasadnienia, powinien zostać zawarty układ oparty na spłatach. Powyższy spór może mieć przełożenie na praktykę orzeczniczą, ponieważ zbyt mocne zaakcentowanie interesów wierzycieli-nabywców w stosunku do pozostałych wierzycieli jest obarczone ryzykiem odmowy zatwierdzenia układu przez sąd na podstawie art. 165 p.r. ${ }^{3}$

Ustawa prawo restrukturyzacyjne, posługując się pojęciami: dewelopera, nabywcy, przeniesienia własności lokalu, umowy deweloperskiej, odwołuje się do definicji zawartych w Ustawie $z$ dnia 16 września 2011 r. o ochronie praw nabywcy lokalu mieszkalnego lub domu jednorodzinnego ${ }^{4}$. Dodatkowo na gruncie art. 350 pkt. 1 p.r. za nabywcę - obok osób fizycznych, uznaje się osoby prawne i ułomne osoby prawne. Również pojęcie przeniesienia własności lokalu jest szersze (art. 350 pkt. 3 p.r.), obejmuje także przeniesienie własności nieruchomości gruntowej zabudowanej domem jednorodzinnym lub użytkowania wieczystego nieruchomości gruntowej i własności domu jednorodzinnego na niej posadowionego stanowiącego odrębną nieruchomość ${ }^{5}$.

${ }^{2}$ Zob. E. Całus, Postępowanie restrukturyzacyjne $i$ upadłościowe wobec deweloperów a ochrona praw nabywcy, „Rejent” 2016, nr 8(304).

${ }^{3}$ D. Chrapoński, w: Prawo restrukturyzacyjne. Komentarz, red. A. Torbus, A. J. Witosz, A. Witosz, Warszawa 2016, LEX, komentarz do art. 352 (dostęp: 11.02.2020 r.).

${ }^{4}$ Zob. Ustawa z 16 września 2011 r. o ochronie praw nabywcy lokalu mieszkalnego lub domu jednorodzinnego (Dz.U. Nr 232, poz. 1377), dalej: u.o.p.n.

${ }^{5}$ M. Porzycki, Upadłość i restrukturyzacja dewelopera, w: Restrukturyzacja 
Restrukturyzacja dewelopera, która miałaby obejmować wierzytelności nabywców oraz wierzytelności zabezpieczone na nieruchomości, na której jest prowadzone przedsięwzięcie deweloperskie, może odbyć się w ramach przyspieszonego postępowania układowego, postępowania układowego oraz sanacyjnego. Ustawa (art. 351 p.r.) wyłącza możliwość przeprowadzenia przez dewelopera postępowania o zatwierdzenie układu, który miałby obejmować tego rodzaju wierzytelności. Powyższe ograniczenie ustawowe wynika $z$ tego, że immanentną cechą postępowania o zatwierdzenie układu jest rozszerzona kontrola dłużnika nad postępowaniem przy minimalnym udziale wierzycieli. Przyjęcie odmiennego rozwiązana wyłączałoby możliwość zgłaszania przez wierzycieli-nabywców własnych propozycji układowych w postępowaniu o zatwierdzenie układu ${ }^{6}$. Deweloper może jednak prowadzić tego rodzaju postępowanie w formie układu częściowego w odniesieniu do pozostałych wierzytelności. Biorąc pod uwagę, że postępowanie o zatwierdzenie układu jest dedykowane dłużnikom, którzy nie posiadają wielu wierzycieli, należy uznać, że tego rodzaju ograniczenie ustawowe nie jest wielce krzywdzące dla dłużnika, gdyż postępowanie deweloperskie co do zasady charakteryzuje się występowaniem dużej liczby wierzycieli-nabywców.

\section{Sposoby restrukturyzacji dewelopera}

Ustawa (p.r.) zarówno w stosunku do postępowań prowadzonych na zasadach ogólnych, jak i postępowań deweloperskich, przewiduje katalog otwarty propozycji układowych, jednocześnie ujmując pewne sugestie odnośnie do sposobów restrukturyzacji. Zgodnie z art. 156 p.r. restrukturyzacja zobowiązań dłużnika obejmuje w szczególności: odroczenie terminu wykonania; rozłożenie spłaty

i upadłość przedsiębiorstw 2.0, red. A. Hrycaj, P. Filipiak, M. Geromin, B. Groele, Warszawa 2016, s. 159.

${ }^{6}$ M. Porzycki, Komentarz do niektórych przepisów ustawy - Prawo restrukturyzacyjne, w: Upadłość i restrukturyzacja deweloperów. Komentarz, Warszawa 2019, LEX, komentarz do art. 351 (dostęp: 11.02 .2020 r.). 
na raty; zmniejszenie wysokości; konwersję wierzytelności na udziały lub akcje; zmianę, zamianę lub uchylenie prawa zabezpieczającego określoną wierzytelność. Odnośnie do deweloperów propozycje układowe mogą również obejmować: wpłacenie dopłat przez wszystkich albo niektórych nabywców i zaspokojenie ich przez przeniesienie własności lokali (przy czym propozycje układowe mogą przewidywać późniejszy zwrot dopłat $\mathrm{z}$ przychodów $\mathrm{z}$ realizacji przedsięwzięcia deweloperskiego); sprzedaż nieruchomości, na której jest prowadzone przedsięwzięcie deweloperskie ( $\mathrm{z}$ zachowaniem ciążących na niej ograniczonych praw rzeczowych), na rzecz przedsiębiorcy, który przejąłby zobowiązania wobec nabywców i zobowiązałby się do kontynuacji przedsięwzięcia deweloperskiego, przy czym propozycje układowe mogą przewidywać zmianę treści umów deweloperskich; określenie innych warunków kontynuacji przedsięwzięcia deweloperskiego i sposobów jego finansowania; zamianę lokali między wierzycielami lub zamianę lokalu na lokal niebędący przedmiotem umowy deweloperskiej. Treść art. 354 p.r. normującego powyższe kwestie zawiera wyłączenie sugestie ustawodawcy co do sposobu restrukturyzacji, mogące okazać się pomocne przy formułowaniu propozycji układowych ${ }^{7}$.

Do złożenia propozycji układowych zobowiązany jest sam dłużnik-deweloper. Dodatkowo propozycje układowe może przedstawić rada wierzycieli, nadzorca sądowy lub zarządca, wierzyciel lub wierzyciele mający łącznie więcej niż 30\% sumy wierzytelności. W postępowaniu deweloperskim legitymację do złożenia propozycji układowych mają także nabywcy, w liczbie stanowiącej co najmniej 20\% liczby nabywców w ramach przedsięwzięcia deweloperskiego prowadzonego przez dłużnika. Nabywcy, którzy zdecydują się na przedstawienie swoich propozycji układowych, muszą zrobić to w terminie $30 \mathrm{dni}$ od dnia otwarcia postępowania restrukturyzacyjnego. W praktyce oznacza to, że aby mieć czynny wpływ na sposób restrukturyzacji, nabywcy są zmuszeni do znacznego wysiłku organizacyjnego, aby

7 P. Zimmermann, w: System prawa handlowego. Tom 6. Prawo restrukturyzacyjne i upadłościowe, red. A. Hrycaj, A. Jakubecki, A. Witosz, Warszawa 2016, s. 548. 
uzgodnić swój zbiorowy interes. Propozycje układowe złożone po terminie mogą nie zostać poddane pod głosowanie, jeśli skutkowałoby to znacznym opóźnieniem i szkodą dla przebiegu postępowania ${ }^{8}$.

Wpłacenie dopłat przez wszystkich lub niektórych nabywców niewątpliwie jest jednym $z$ najbardziej naturalnych sposobów restrukturyzacji dewelopera ${ }^{9}$. Przegłosowanie tego rodzaju propozycji układowych, nie oznacza jednak, że wierzyciele-nabywcy, którzy zagłosowali przeciwko układowi, mogą zostać przymusowo zobowiązani do dopłat. Taki wariant byłyby oczywiście niesprawiedliwy. Pamiętać należy, że przymusowe wyegzekwowanie dopłat w wielu przypadkach byłoby po prostu nierealne. W praktyce przyjęcie powyższego sposobu restrukturyzacji będzie wiązało się $z$ sytuacją, w której wsparcie przedsięwzięcia deweloperskiego przez nabywców może być zróżnicowane, dlatego ustawa zezwala na odmienne traktowanie wierzycieli w zależności od tego, czy wniosą oni dopłaty czy nie (art. 355 ust. 1 p.r.). Wniesienie dopłat przez wierzycieli-nabywców będzie pożądane w sytuacji, gdy dokończenie ich mieszkań (domów jednorodzinnych) jest realne i ekonomicznie uzasadnione, w szczególności gdy poziom zaawansowania robót jest znaczny ${ }^{10}$. Propozycje układowe powinny przewidywać dopłaty na poziomie umożliwiającym dokończenie przedsięwzięcia deweloperskiego, w konsekwencji mogą być one wyższe od ceny nabycia lokalu ${ }^{11}$. Wśród komentatorów nie ma zgody co do kwestii ustalenia wysokości dopłat wnoszonych przez nabywców, bo choć dominuje pogląd $^{12}$ o możliwości ujęcia ich $\mathrm{w}$ formie widełkowej, to pojawiają się również głosy o konieczności ustalenia dopłat sztywno, kwotowo ${ }^{13}$. Propozycje układowe mogą przewidywać późniejszy zwrot dopłat

${ }^{8}$ P. Zimmermann, P. Filipiak, B. Sierakowski, A. Michalska, Prawo restrukturyzacyjne. Komentarz do ustawy, Warszawa 2017, s. 606-607.

9 M. Porzycki, w: Prawo restrukturyzacyjne. Komentarz, red. P. Filipiak, A. Hrycaj, Warszawa 2017, LEX, komentarz do art. 354 (dostęp: 13.02.2020 r.).

${ }^{10}$ D. Chrapoński, Prawo restrukturyzacyjne, komentarz do art. 354 (dostęp: 13.02.2020 r.).

11 Zob. ibidem, komentarz do art. 354 (dostęp: 13.02.2020 r.).

12 Zob. P. Zimmermann, System, s. 549.

${ }^{13}$ D. Chrapoński, Prawo restrukturyzacyjne, komentarz do art. 354 (dostęp: 17.02.2020 r.). 
z przychodów $\mathrm{z}$ realizacji przedsięwzięcia deweloperskiego (art. 354 ust. 1 pkt 1 p.r.) i potraktowanie dopłat jako pożyczki ${ }^{14}$.

Pisemny głos nabywcy w przyspieszonym postępowaniu układowym, postępowaniu układowym lub postępowaniu sanacyjnym, w którym dłużnikowi udzielono zezwolenia na wykonywanie zarządu nad przedsiębiorstwem w całości lub w części, zawierający zobowiązanie do wpłacenia dopłaty zgodnie $z$ propozycjami układowymi, łącznie $z$ wypisem prawomocnego postanowienia zatwierdzającego układ, stanowi tytuł egzekucyjny przeciwko nabywcy, który oddał głos za przyjęciem układu (art. 357 p.r.). Takie rozwiązanie należy ocenić pozytywnie, ponieważ daje dłużnikowi instrument do stosunkowo sprawnego wyegzekwowania zobowiązania nabywców, bez szkody dla postępowania, która mogłaby powstać przy opóźnieniu we wnoszeniu dopłat. Przyjmuje się, że w przypadku określenia w propozycjach układowych wysokości dopłat w formie widełkowej egzekucję wobec nabywcy, można prowadzić do kwoty maksymalnej z zaproponowanego przedziału ${ }^{15}$.

Zgodnie $z$ treścią art. 354 ust. 1 pkt. 2 p.r. propozycje układowe mogą przewidywać także przejęcie przedsięwzięcia deweloperskiego i jego kontynuacje przez nowego inwestora - przedsiębiorcę, z zachowaniem ciążących na nieruchomości ograniczonych praw rzeczowych i możliwością modyfikacji treści umów deweloperskich. Tego rodzaju sposób restrukturyzacji będzie uzasadniony ekonomicznie dla inwestorów, w przypadku gdy w ramach realizacji przedsięwzięcia deweloperskiego pozostały wolne lokale, $z$ których sprzedaży nowy inwestor będzie mógł osiągnąć zysk. Propozycje układowe, o treści odpowiadającej art. 354 ust. 1 pkt 2 p.r., mogą okazać się sensownym sposobem restrukturyzacji także dla nabywców, którzy wystąpią w charakterze inwestora w ramach utworzonej w tym celu spółki $^{16}$. Realizacja układu na powyższych zasadach $\mathrm{w}$ praktyce wiąże się z koniecznością wypracowania przez inwestora porozumie-

${ }^{14}$ M. Porzycki, Prawo restrukturyzacyjne, komentarz do art. 354 (dostęp: 17.02.2020 r.).

15 P. Zimmermann, System, s. 549.

${ }^{16}$ Zob. Uzasadnienie do projektu ustawy - Prawo restrukturyzacyjne, druk Sejmu VII kadencji nr 2824, http://www.sejm.gov.pl (dostęp 14.03.2020 r.). 
nia $z$ wierzycielami zabezpieczonymi rzeczowo na nieruchomości ${ }^{17}$. Dopuszczalne wydaje się przeprowadzenie przy udziale nowego inwestora restrukturyzacji w stosunku do części nieruchomości, na której realizowane jest przedsięwzięcie deweloperskie. W takim przypadku konieczne będzie wyodrębnienie części nieruchomości oraz podział hipoteki ${ }^{18}$. Rozwiązanie takie może okazać się pożądane, szczególnie w przypadku, gdy wola restrukturyzacji objawia się np. wyłącznie w obrębie jednego bloku mieszkalnego. Restrukturyzacja oparta na włączeniu się inwestora zewnętrznego lub wewnętrznego (spółki celowej wierzycieli - nabywców) wymaga załączenia do propozycji układowych oświadczenia tegoż przedsiębiorcy o nabyciu nieruchomości, na której jest prowadzone przedsięwzięcie deweloperskie, wraz z ciążącymi na niej obciążeniami i przejęciu zobowiązań podmiotu poddanego restrukturyzacji w stosunku do nabywców. Oświadczenie musi mieć formę aktu notarialnego oraz ma charakter nieodwołalny. W przypadku prawomocnego zatwierdzenia układu oświadczenie inwestora zastępuje jego oświadczenie woli konieczne do zawarcia umowy sprzedaży nieruchomości, na której jest prowadzone przedsięwzięcie deweloperskie, a umowę uznaje się za zawartą. Prawomocne postanowienie o zatwierdzeniu układu wraz $\mathrm{z}$ oświadczeniem inwestora stanowi podstawę ujawnienia prawa własności w księdze wieczystej ${ }^{19}$. W przypadku gdy dla przedsięwzięcia deweloperskiego jest prowadzony powierniczy rachunek mieszkaniowy, nowy inwestor jest zobligowany do zawarcia w terminie 30 dni od dnia uprawomocnienia się postanowienia o zatwierdzeniu układu umowy o prowadzenie powierniczego rachunku mieszkaniowego. O fakcie zawarcia tejże umowy inwestor powinien niezwłocznie powiadomić dłużnika, który jest zobowiązany (zarządca $\mathrm{w}$ sanacji) do przelania środków $\mathrm{z}$ rachunku powierniczego dłużnika na nowy rachunek inwestora ${ }^{20}$.

17 P. Zimmermann, P. Filipiak, B. Sierakowski, A. Michalska, Prawo restrukturyzacyjne, s. 609.

${ }_{18}$ M. Porzycki, Komentarz, komentarz do art. 354 (dostęp: 19.02 .2020 r.).

19 P. Zimmermann, P. Filipiak, B. Sierakowski, A. Michalska, Prawo restrukturyzacyjne, s. 612.

${ }^{20}$ D. Chrapoński, Prawo restrukturyzacyjne, komentarz do art. 355 (dostęp: 20.02.2020 r.). 
Restrukturyzacja dewelopera może opierać się na innych propozycjach układowych określających odmienne warunki kontynuacji przedsięwzięcia deweloperskiego i sposoby jego finansowania (art. 354 ust. 1 pkt 3 p.r.). Propozycje układowe powinny jednak rozstrzygać kwestię zaspokojenia wierzycieli rzeczowych, posiadających zabezpieczenia hipoteczne na nieruchomości. Bez uregulowania kwestii spłaty ich zobowiązań restrukturyzacja praktycznie zawsze będzie nieskuteczna ${ }^{21}$.

Zamiana lokali między wierzycielami lub zamiana na lokal niebędący przedmiotem umowy deweloperskiej, wskazane jako ostatnia propozycja sposobu restrukturyzacji (art. 354 ust. 1 pkt 4 p.r.), również de facto będzie prowadzić do zaspokojenia potrzeb mieszkaniowych nabywców, więc wpisuje się w założenia celów postępowania deweloperskiego sensu largo. Jest to forma restrukturyzacji przede wszystkim dedykowana postępowaniom, w którym pozyskanie dopłat od wszystkich nabywców będzie nieosiągalne. W takim przypadku wierzyciele, których nie stać na dopłaty, mogą otrzymać mniejsze lokale, a różnica w ich cenie będzie potraktowana jako dopłata ${ }^{22}$.

Należy pamiętać, że warunki restrukturyzacji powinny być jednakowe dla wszystkich wierzycieli danej grupy (np. nabywców), chyba że konkretny wierzyciel wyrazi zgodę na mniej korzystne warunki. Dla przykładu: zamiana lokali musi zostać poparta w każdym przypadku indywidualną zgodą zainteresowanych, w przeciwnym razie układ może zostać niezatwierdzony jako niezgodny $z$ prawem, gdyż tego rodzaju warunki restrukturyzacji należy uznać za mniej korzystne niż te przewidziane dla ogółu wierzycieli ${ }^{23}$.

\section{Głosowanie nad układem}

Głosowanie nad układem obligatoryjnie przeprowadza się w grupach wierzycieli, ponieważ nabywcy zawsze muszą stanowić od-

${ }^{21}$ P. Zimmermann, System, s. 550.

${ }^{22}$ P. Zimmermann, P. Filipiak, B. Sierakowski, A. Michalska, Prawo restrukturyzacyjne, s. 609.

${ }^{23}$ Ibidem, s. 609-610. 
rębną grupę. Celem takiego rozwiązania jest ochrona nabywców przed narzuceniem im niekorzystnego układu przez pozostałych wierzycieli - przy głosowaniu w grupach układ jest przyjęty, jeżeli w każdej grupie wypowie się za nim większość głosujących wierzycieli $z$ tej grupy, mających łącznie co najmniej dwie trzecie sumy wierzytelności przysługujących głosującym wierzycielom $z$ tej grupy (art. 119 ust. 2 p.r.). Układ zostaje przyjęty, chociażby nie uzyskał wymaganej większości w niektórych $\mathrm{z}$ grup wierzycieli, jeżeli wierzyciele mający łącznie dwie trzecie sumy wierzytelności przysługujących głosującym wierzycielom głosowali za przyjęciem układu, a wierzyciele $z$ grupy lub grup, które wypowiedziały się przeciw przyjęciu układu, zostaną zaspokojeni na podstawie układu w stopniu nie mniej korzystnym niż w przypadku przeprowadzenia postępowania upadłościowego (art. 119 ust. 3 p.r.). W efekcie będą występować co najmniej dwie grupy - jedna obejmująca nabywców i druga - pozostałych wierzycieli ${ }^{24}$. Dla nabywców, stanowiących odrębną grupę, sporządza się osobną listę wierzycieli uprawionych do głosowania. Dopuszczalny jest także dodatkowy podział nabywców na większą liczbę grup obejmujących poszczególne kategorie interesów, w szczególności z uwagi na stopień wykonania umowy $z$ deweloperem (art. 356 p.r.).

\section{Wstępne głosowanie nad propozycjami układowymi w postępowaniu sanacyjnym}

W postępowaniu deweloperskim, sanacyjnym, w którym dłużnikowi nie udzielono zezwolenia na wykonywanie zarządu nad całością lub częścią przedsiębiorstwa w zakresie nieprzekraczającym zakresu zwykłego zarządu, obligatoryjnie przeprowadza się wstępne głosowanie przez nabywców nad propozycjami układowymi, o ile przewidują one wpłacenie dopłat przez wszystkich albo niektórych nabywców.

${ }^{24}$ M. Porzycki, Prawo restrukturyzacyjne, komentarz do art. 354 (dostęp: 17.02.2020 r.). 
Głosownie to ma na celu przede wszystkim ustalenie, czy po stronie nabywców istnieje wola co do takiego sposobu restrukturyzacji ${ }^{25}$. Ponieważ głosowanie wstępne powinno odbyć się jak najszybciej od daty otwarcia postępowania, do ustalenia wierzycieli-nabywców nie jest konieczny spis wierzytelności, wystarczy lista nabywców uprawionych do głosowania sporządzona przez sędziego - komisarza na podstawie listy przedłożonej mu przez zarządcę. Uchwała nabywców jest przyjęta, jeżeli opowiedzą się za nią nabywcy deklarujący dopłaty, które łącznie - zgodnie $z$ treścią propozycji układowych będą wystarczające do sfinansowania dokończenia przedsięwzięcia deweloperskiego ${ }^{26}$. Nabywcy, którzy zobowiązali się w uchwale do wniesienia dopłat do masy sanacyjnej, mają obowiązek to uczynić w terminie dwóch miesięcy od dnia podjęcia uchwały. Niniejszy wymóg będzie zachowany, jeśli nabywca dokona zabezpieczenia ich wpłaty w tym terminie. Ustawa (p.r.) nie precyzuje, w jakiej formie powinno być wniesione zabezpieczenie, natomiast powinno ono gwarantować realne zaspokojenie roszczeń o wpłatę dopłat ${ }^{27}$. W szczególnie uzasadnionych przypadkach termin dwumiesięczny może zostać przedłużony postanowieniem sędziego-komisarza (art. 359 ust. 1 zd. 2 p.r.). Głosowanie wstępne zostało ograniczone wyłącznie do postępowania sanacyjnego, w którym dłużnik nie wykonuje zarządu, gdyż tylko zewnętrzny zarządca może dać rękojmię bezpieczeństwa tychże środków, gromadzonych przed datą zatwierdzenia układu ${ }^{28}$.

Może zaistnieć sytuacja, że w terminie dwumiesięcznym nie zostaną wpłacone lub zabezpieczone wszystkie dopłaty w pełnej wysokości przewidzianej uchwalą. W takim przypadku nabywcy, którzy już wnieśli dopłaty, mogą uiścić brakujące kwoty niezbędne do sfinansowania przedsięwzięcia deweloperskiego (lub dokonać ich zabezpieczenia) w terminie 30 dni od bezskutecznego upływu terminu pierwotnego. Oczywiście ustawa nie wyklucza tego, żeby w terminie 30-dniowym pozostali wierzyciele, którzy nie wnieśli

25 P. Zimmermann, System, s. 553.

${ }^{26}$ M. Porzycki, Prawo restrukturyzacyjne, komentarz do art. 358 (dostęp: 17.02.2020 r.).

${ }^{27}$ Idem, Komentarz, komentarz do art. 359 (dostęp: 1.03.2020 r.).

${ }^{28}$ Ibidem, komentarz do art. 358 (dostęp 1.03.2020 r.). 
dopłat, a nawet wcześniej głosowali przeciwko uchwale, mogli również je uiścić. Dłużnik lub zarządca w tym dodatkowym terminie mogą przedstawić dowód istnienia innych źródeł finansowania przedsięwzięcia deweloperskiego. Wszystkie te rozwiązania mają na celu stworzenie możliwości uzyskania źródeł finansowania, w sytuacji gdy wierzyciele, którzy głosowali za uchwałą w głosowaniu wstępnym, nie chcą lub nie mogą wywiązać się ze zobowiązania do wniesienia dopłat ${ }^{29}$. Środki pieniężne uzyskane $z$ dopłat zarządca przechowuje na odrębnym rachunku bankowym (art. 359 ust. 4 p.r.). W przypadku bezskutecznego upływu obu terminów na dokonanie wpłat odpowiednio uprawione podmioty mogą złożyć nowe propozycje układowe w terminie $30 \mathrm{dni}$. Nowe propozycje układowe przewidujące wpłacenie dopłat przez nabywców są niedopuszczalne (art. 359 ust. 5 p.r.). Zgromadzenie wystarczających środków w trybie art. 359 ust. 1 i 2 p.r. na sfinansowanie przedsięwzięcia deweloperskiego stwierdza postanowieniem sędzia-komisarz, jednocześnie wyznaczając termin zgromadzenia wierzycieli w celu głosowania nad układem (art. 359 ust. 3 p.r.). Treść uchwały nabywców, podjętej w trybie głosowania wstępnego, włącza się do układu, a następnie zwołane zgromadzenie wierzycieli nie może przyjąć układu o treści odbiegającej od uchwały nabywców w zakresie, jaki jest przez tę uchwałę uregulowany. Sędzia-komisarz jest zobligowany do zwrócenia uwagi wierzycielom uczestniczącym w zgromadzeniu na przypadki niezgodności propozycji układowych $\mathrm{z}$ uchwalą nabywców. Układ odbiegający treścią od uchwały nabywców w zakresie nią uregulowanym zostanie niezatwierdzony przez sąd ${ }^{30}$.

\section{Niepowodzenie restrukturyzacji dewelopera}

Kiedy restrukturyzacja zakończy się niepowodzeniem, na skutek prawomocnej odmowy zatwierdzenia układu (umorzenia postępo-

29 P. Zimmermann, System, s. 555-556.

${ }^{30}$ P. Zimmermann, P. Filipiak, B. Sierakowski, A. Michalska, Prawo restrukturyzacyjne, s. 617. 
wania sanacyjnego), nabywcy otrzymują zwrot wniesionych dopłat, powiększonych o należne odsetki zgodnie $z$ umową rachunku bankowego, zabezpieczenia wpłaconych dopłat wygasają natomiast z mocy prawa ${ }^{31}$. Jeżeli jednak postępowanie restrukturyzacyjne przybrało formę sanacji i złożony został uproszczony wniosek o ogłoszenie upadłości, po ogłoszeniu upadłości wniesione dopłaty zostają przekazane przez zarządcę do syndyka, który może kontynuować przedsięwzięcie deweloperskie. Środki pieniężne uzyskane $z$ dopłat, przechowywane przez zarządcę po umorzeniu postępowania sanacyjnego, wyłącza się spod egzekucji sądowej i administracyjnej przeciwko dłużnikowi, aby żaden $z$ innych wierzycieli nie mógł zaspokoić się z tych środków. W przypadku gdy przedsięwzięcie deweloperskie nie może być zrealizowane przez syndyka w upadłości, nabywcy otrzymują zwrot dopłat w pełnej wysokości ${ }^{32}$.

\section{Zgoda na bezobciążeniowe wyodrębnienie nieruchomości}

Obligatoryjnym elementem umowy deweloperskiej jest informacja o zgodzie banku lub innego wierzyciela zabezpieczonego hipoteką na bezobciążeniowe wyodrębnienie lokalu mieszkalnego i przeniesienie jego własności po wpłacie pełnej ceny przez nabywcę, jeżeli takie obciążenie istnieje, albo informacja o braku takiej zgody, albo informacja o zgodzie banku lub innego wierzyciela zabezpieczonego hipoteką na bezobciążeniowe przeniesienie na nabywcę własności nieruchomości wraz z domem jednorodzinnym lub użytkowanie wieczyste nieruchomości gruntowej i własności domu jednorodzinnego stanowiącego odrębną nieruchomość lub przeniesienie ułamkowej części własności nieruchomości wraz z prawem do wyłącznego korzystania z części nieruchomości służącej zaspokajaniu potrzeb mieszkaniowych po wpłacie pełnej ceny przez nabywcę, jeżeli takie obciążenie istnieje, albo informacja o braku takiej zgody (art. 22

31 P. Zimmermann, System, s. 552-553.

32 B. Sierakowski, P. Zimmermann, Postępowania restrukturyzacyjne wobec deweloperów, „Monitor Prawa Bankowego” 2015, nr 12, s. 113. 
ust. 1 pkt 17 u.o.p.n.). Zgodnie $z$ prawem restrukturyzacyjnym (art. 361 p.r.), jeżeli nieruchomość, na której jest prowadzone przedsięwzięcie deweloperskie, jest obciążona hipoteką, której przysługuje pierwszeństwo przed roszczeniami chociażby jednego nabywcy, a wierzyciel zabezpieczony hipoteką wyraził zgodę na bezobciążeniowe wyodrębnienie lokalu mieszkalnego, zgoda taka pozostaje w mocy na warunkach w niej określonych, przy czym warunek wykonania zobowiązania nabywcy względem dłużnika uznaje się za spełniony w przypadku wykonania zobowiązania do rąk zarządcy. Uznaje się, że art. 361 prawa restrukturyzacyjnego, pomimo że w dosłownym brzmieniu odnosi się tylko do nabywców lokali mieszkalnych, zgodnie $z$ wykładnią systemową obejmuje również przypadki bezobciążeniowego przeniesienia własności nieruchomości zabudowanej domem jednorodzinnym lub użytkowania wieczystego nieruchomości gruntowej i własności posadowionego na niej domu jednorodzinnego ${ }^{33}$. Po nowelizacji art. 361 p.r., która wchodzi w życie 24 marca 2020 r., zakres regulacji ujętej w przepisie będzie obok zgody na bezobciążeniowe wyodrębnienie lokalu mieszkalnego obejmował również zobowiązanie do jej wydania (utrzymanie w mocy).

\section{Wnioski końcowe}

Odrębne postępowanie restrukturyzacyjne dedykowane deweloperom uwzględnia szereg instytucji, które jednocześnie mają chronić prawa nabywców lokali oraz ułatwiać prowadzenie skutecznego postępowania. Trzeba jednak wyraźnie zaakcentować, że tego rodzaju postępowanie naprawcze nie stanowi remedium na wszystkie bolączki związane $z$ kryzysem podmiotu prowadzącego przedsięwzięcie deweloperskie. Sukces restrukturyzacji jest bowiem uzależniony do sprawnej reakcji dewelopera na stan zagrożenia niewypłacalnością oraz aktywnej partycypacji wierzycieli-nabywców. Zasadnicze znaczenie dla efektywności postępowania ma także w dużej mierze zgoda wierzyciela hipotecznego na bezobciążeniowe wyodrębnienie

${ }^{33}$ P. Zimmermann, P. Filipiak, B. Sierakowski, A. Michalska, Prawo restrukturyzacyjne, s. 619-621. 
lokalu, udzielona w momencie zawierania umowy deweloperskiej, ponieważ bez niej nie będzie możliwe w toku restrukturyzacji nabycie lokalu po zakończeniu inwestycji w stanie wolnym od obciążeń ${ }^{34}$.

\section{STRESZCZENIE}

Postępowanie restrukturyzacyjne wobec deweloperów

Niniejszy artykuł porusza tematykę odrębnego postępowania restrukturyzacyjnego wobec deweloperów, którego zasadniczym celem jest zaspokojenie nabywców w drodze przeniesienia na nich własności lokali. W artykule szczegółowo omówiono najczęściej spotykane w obrocie sposoby restrukturyzacji oraz szczególne instrumenty postępowania deweloperskiego służące skutecznej restrukturyzacji oraz ochronie praw nabywców lokali.

Słowa kluczowe: restrukturyzacja; deweloper; nabywca; propozycje układowe; dopłaty; wierzyciel; głosowanie nad układem

\section{SUMMARY}

\section{Restructuring proceeding of developers}

This article is about of restructuring proceedings of developers, whose primary purpose is to satisfy buyers by transferring ownership of the premises to them. The article discusses in detail the most common restructuring methods and specific instruments for effective restructuring and protection of the rights of purchasers of premises.

Keywords: restructuring; developer; buyer; composition proposals; subsidies; creditor; voting on agreements with creditors

\section{BIBLIOGRAFIA}

Całus E., Postępowanie restrukturyzacyjne i upadłościowe wobec deweloperów a ochrona praw nabywcy, „Rejent” 2016, nr 8(304).

${ }^{34}$ B. Sierakowski, P. Zimmermann, Postępowania, s. 116. 
Hrycaj A., Jakubecki A., Witosz A., System prawa handlowego. Tom 6. Prawo restrukturyzacyjne $i$ upadłościowe, Warszawa 2016.

Filipiak P., Michalska A., Sierakowski B., Zimmermann P., Prawo restrukturyzacyjne. Komentarz do ustawy, Warszawa 2017.

Filipiak P., Hrycaj A., Prawo restrukturyzacyjne. Komentarz, Warszawa 2017, LEX.

Porzycki M., Upadłość i restrukturyzacja dewelopera, w: Restrukturyzacja i upadłość przedsiębiorstw 2.0, red. A. Hrycaj, P. Filipiak, M. Geromin, B. Groele, Warszawa 2016.

Porzycki M., Upadłość i restrukturyzacja deweloperów. Komentarz, Warszawa 2019, LEX.

Sierakowski B., Zimmermann P., Postępowania restrukturyzacyjne wobec deweloperów, „Monitor Prawa Bankowego” 2015, nr 12.

Torbus A., Witosz A. J., Witosz A., Prawo restrukturyzacyjne. Komentarz, Warszawa 2016, LEX. 
